\title{
Management Counseling Guidance at SMA Negeri 1 Sekayu
}

\author{
David $^{1 *}$, Happy Fitria ${ }^{2}$, Rohana ${ }^{2}$ \\ ${ }^{1}$ SMA Negeri 1 Sekayu, Sumatera Selatan, Indonesia \\ ${ }^{2}$ Universias PGRI Palembang \\ *Corresponding author. Email: Davidwahyu327@gmail.com
}

\begin{abstract}
This research is intended to describe: the planning guidance and counseling, implementation guidance and counseling, counseling supervision in SMA Negeri 1 Sekayu. This type of research is a qualitative descriptive study. The techniques used for data collection are interviews, observation, and documentation. The results of the study state that 1) Planning for guidance and counseling is carried out by the Guidance and Counseling coordinator and assisted by the Guidance and Counseling teacher in accordance with the guidance and counseling curriculum which consists of personal, social, learning and career guidance and the implementation is carried out in classical, group and individual ways. ;2) Planning is compiled based on a feasibility study, work program, preparation of facilities and facilities, preparation of instruments and procurement of coordination meetings; 3 ) Implementation of Guidance and Counseling covering personal, social, learning, career aspects, with service delivery techniques in groups and individually; 4) Supervision of guidance and counseling is carried out by the principal, namely; student orientation, information, placement, learning, individual, group counseling and one-on-one counseling services.
\end{abstract}

Keywords: Management, Guidance, Counseling

\section{INTRODUCTION}

Education is one means of improving the quality of human resources. To increase the effectiveness and efficiency of education, it is necessary to improve the quality of education management, related to this problem, educational management which is expected to produce productive education, that is effective and efficient, requires an analysis of the culture or values of important ideas in various dimensions of life that are available for a sufficient period of time in which humans live.

Education is a major element in human resource development, both formally and informally. With the existence of education, humans can become more moral and look back on things that were never known before [1]. Meanwhile, an education is a system that affects each other and pays in achieving educational goals in accordance with what is expected together [2].

Leadership and management in schools play a very important role in achieving goals. More appropriate leadership and management needs to be sought for schools because of these fundamental changes, the previous leadership and management system has become less than optimal for leadership and managing schools today [3].

Management is a process that uses human resources and other resources to achieve a goal, while management as a science and art regulates the process of utilizing human resources and other resources efficiently, effectively and proactively in achieving a goal. So that it can be interpreted simply that management is an effort, planning, organizing, directing, coordinating and supervising activities in an organization so that organizational goals are achieved efficiently and effectively [4].

Teachers and school management play an important role in improving the quality of education, so there is a need for a certain pattern and good school management in improving teacher professionalism through counseling. Counseling guidance can be done by providing facilities for teachers to develop their abilities.

Guidance is part of an educational program that fosters student development. Students as school members need help because they are in a development process, where students experience obstacles and difficulties due to the lack of understanding of themselves and their environment [5].

In order for guidance and counseling services to run optimally, school counselors need good managerial activities, and managerial abilities are actually one of the competencies that school counselors must have. 
Permendiknas No. 27 of 2008 concerning Academic Qualification Standards and Counselor Competencies states that a school counselor must master all the competencies that have been determined, one of the competencies that must be mastered is the 13-15 professional competence, namely a counselor is required to be able to carry out guidance management and counseling [6]. Guidance and counseling management are all activities starting from planning, organizing, implementing and evaluating in the field of guidance and counseling.

Counseling guidance provided by the teacher will be able to increase learning achievement in particular and will also be able to increase discipline, motivation, and obedience to existing school rules. The problem is, the school or the principal may pay less attention to the management of counseling-guided medication in schools. Many teachers (especially BK teachers) provide limited assistance to children (students) who have problems while students who have advantages / potential have not received good counseling guidance. Actually, students who have potential advantages over other students really need to get counseling guidance to develop their potential and provide information that is expected to be useful for their selfdevelopment. However, in its implementation, this management aspect is still neglected, causing problems, especially in the management of guidance and counseling services.

Among the many problems that arise in schools related to counseling guidance management are: 1) the position and role of counseling guidance in schools including the position of the counseling guidance organization in the school organizational structure; 2) there are still many counseling guidance teachers who do not have counseling guidance educational background; 3) preparation and implementation of counseling guidance programs that have not utilized a good management system; 4 ) the existence of a school policy on the absence of BK hours, which means that BK activities are carried out more outside of learning hours which results in less optimal implementation of guidance and counseling in schools so that students do not develop optimally.

Therefore, the role of counseling guidance management is very necessary. Especially in an institution such as a school so that in BK a school can be structured and its implementation is clear. So that it can be seen clearly when evaluated on which parts need to be improved. And more mature planning can be made so that the implementation of counseling guidance is even better. Based on the above background, the writer is interested in discussing "Management of learning counseling guidance for students at SMA N 1 Sekayu".

\section{METHODS}

This research was conducted at SMA Negeri 1, Sekayu District, Musi Banyuasin Regency, South Sumatra Province, Indonesia. Data collection tools use interviews, documentation and observation. The research sources were the principal, the vice principal, and the BK teacher at SMA Negeri 1 Sekayu.

Data analysis using qualitative data collection techniques includes the process of data reduction, data presentation and drawing conclusions to obtain a general and comprehensive picture of the object of research.

\section{RESULTS AND DISCUSSION}

Based on the findings through data collection, it was found that the principal's competence in improving the quality of the library was carried out through the first stage, namely the formulation of a library quality improvement program. The second stage is the implementation of the library quality improvement program which consists of: 1) maximizing library services, 2) maximizing the role of library human resources and 3) maximizing library facilities.

\section{Management Concept}

Management is a process to plan, organize, lead and control the organization's efforts with all its aspects so that organizational goals effectively and efficiently [7]. The planning function is further explained, among others, determining the objectives and framework needed to achieve certain goals. Organizing functions include determining functions, relationships and structures. Functions are tasks that are divided into line, staff, and functional functions. Relationships consist of responsibility and authority. While the structure can be horizontal and vertical. All of this smoothens the allocation of resources with the right combination to implement the plan. The function of the leader describes how managers direct and influence subordinates, how others carry out essential tasks by creating a pleasant atmosphere to work together. The supervisory function includes setting standards, supervising, and measuring the appearance / implementation of standards and providing assurance that organizational goals are achieved. Supervision is closely related to planning, because through monitoring management effectiveness can be measured.

\section{Management Principles}

In management, there are principles which are general guidelines or the main guidelines for the implementation of managerial activities, which determine the success of organizational 
management. General principles of management as the views of Henry Fayol is as follows: 1) division of work (principle of the division of labor), 2) authority and responsibility (principle of authority and responsibility), 3) discipile (principle of discipline), 4) unity of command, 5) unity of direction, 6) subordination of individual interest into general interest (principle of general interests over personal interests), 7) renumeration of personnel ( the principle of fair distribution of salary), 8) centralization (principle of centralization of authority); 9) scalar of chain (principle of hierarchy or periodic chain principle); 10) order (principle of regularity); 11) equity (principle of justice), 12) initiative (principle of initiative); 13) esprit decorp (principle of unity), 14) stability of turn-over personnel (the principle of stability in office) [8]. Management has principles that sincerity, honesty, trust, fairness, responsibility, dynamic, practical and flexible [9].

\section{Management Guidance}

Guidance management is seen as a field of knowledge, as a trick because management achieves goals through means of managing other people to carry out their duties, as a profession because management is based on special expertise and is demanded by a code of ethics. Management guidance includes the following activities: (1) planning; (2) organizing; (3) actuating; and (4) controlling.

Management is the ability and special skills to do an activity/job with other people in achieving organizational goals [10]. Management is the science and art of regulating the process of utilizing human resources and other resources effectively and efficiently to achieve certain goals [11].

School management is the entire school management activity so that all the potential of the school functions optimally in supporting the achievement of school goals. In simple terms, the process includes 4 steps school management, namely: (1) planning; (2) organizing; (3) actuating, and (4) controlling which is abbreviated as POAC [12].

\section{Developing A Program Counseling}

Developing a program consisting of counseling guidance into several steps, namely: 1) preparation; 2) initial meeting between the counselor and other Counseling Guidance officers; 3) establishment of a provisional committee; 4) forming a program organizing committee.

The simple steps taken by SMA Negeri 1 Sekayu in preparing the Counseling Guidance program are: (1) identification of needs, especially the needs of the target subject for counseling guidance. This is done by collecting student data; (2) preparation of programs that produce service units and support units (satlah and satkung). Satlan and satkung are applied activities to achieve the objectives of counseling guidance; (3) determine the priority sequence of activities; (4) ratify it to the principal; (5) program implementation and (6) evaluation.

From these programs, special programs emerge, including: (A) testing program. The implementation of this testing program is based on the principle that, (1) Every student in a school has different abilities; (2) Each student has differences in terms of talents, interests, IQ, EQ, SI; (3) Counselors face relatively different students from one year to the next. Objective testing programs include, but are not limited to, the ability to understand students, the ability to diagnose learning difficulties of students, the placement of students and the ability to measure students. (B) the Orientation and Information Program. The aim of the orientation program is to provide students with an introduction to the state of their school, educational activities at school, school rules and so on. The orientation program is carried out with lectures, discussions, observations, field trips, leaflets, and home rooms. (C) data collection program. Data collection activities aim to make schools have complete information about the condition of students. Usually done at the beginning of the year along with the testing program. The types of data required include socio-economic conditions, family conditions, environmental conditions, health conditions, mental conditions, religion and so on. D) Counseling program. Counseling aims to provide assistance to students who have problems and are unable to solve their own problems. E) Counseling guidance organization. Counseling guidance services are carried out in an integrated, collaborative manner, which means that counseling is the shared responsibility of all education personnel in the school (school principal, BK coordinator, BK teacher, homeroom teacher, subject teacher). In accordance with the provisions of the Education and Culture, it is required that all schools have a counselor as a professional person in charge of implementing counseling services with a ratio of 1: 150 .

In counseling guidance services, the school principal is fully responsible for the implementation of the counseling guidance service so that it must coordinate with all its staff.

\section{Deploy n Guidance}

Tutoring is the process of providing assistance to students in an effort to prevent and overcome learning difficulties. In the discussion in this chapter the focus is on tutoring services, namely assistance aimed at students who have learning difficulties. The steps for tutoring services themselves refer to the 
steps (procedures) of guidance services which include: (a) identification of cases, (b) identification of problems, (c) diagnosis, (d) prognosis, (e) problem solver (treatment), and (f) evaluation and follow-up

\section{Counseling Guidance Results}

The counseling guidance carried out is expected to change behavior from bad to better in terms of personal, social, learning and career aspects. In principle, the counseling guidance provided to students is to assist children in developing themselves both from psychological and psychological aspects.

Some of these aspects will affect the child's learning process, which in general will appear in the form of difficulties in children's learning. The causes of learning difficulties can be grouped into two major parts, namely internal factors and external factors. Internal factors (originating from within students) include intellectual abilities, affective abilities such as feelings and selfconfidence, motivation, maturity to learn, age, gender, social background, study habits, memory skills, and sensory abilities such as seeing, hearing or feel. Meanwhile, external factors (coming from outside students) include factors related to teaching and learning conditions, namely teachers, the quality of the teaching and learning process, and the environment.

\section{a. Efforts to Overcome Learning Difficulties}

To overcome learning difficulties that arise, the following steps are taken: 1) identify any learning difficulties. Symptoms of the emergence of learning difficulties can be observed in various forms. can not appear in the form of deviant behavior changes or decreased learning outcomes. Deviant behavior includes annoying friends, damaging learning tools, difficulty focusing attention, and so on; 2) determine student status. After identifying the emergence of learning difficulties in students, efforts must be made to examine students by examining or determining student status; 3 ) estimating the causes of learning difficulties. Based on the predetermined status, then estimate the causes of learning difficulties experienced by students based on the symptoms of complex difficulties, and 4) the principles of solving learning difficulties.

Learning success is characterized by the ability or skills that were not previously possessed that emerged after carrying out the learning process. To determine the success of learning, an assessment is carried out. One thing that is often forgotten by teachers, is about a person's ability or ability to transfer the abilities obtained from learning outcomes into new situations in a wider scope of life. The ability to better transfer learning outcomes can be achieved if the learning outcomes obtained are of higher degree.

\section{b. Discipline}

Another guidance material is student discipline. Discipline is compliance and obedience to rules or regulations. A student is said to be disciplined if he obeys the rules and regulations. Discipline factors consist of being obedient, orderly, orderly, conscious. While the benefits of discipline that are obtained from the disciplinary attitude possessed by students include: (1) can develop a sense of responsibility for students; (2) can discipline students themselves, (3) can develop students' own creativity: (4) can be on time which is determined / targeted: (5) can take lessons from what he has done.

The discipline of SMA Negeri 1 Sekayu students is generally regulated in school rules such as: (1) attending school no later than 10 minutes before the lesson starts and lining up regularly in front of the class after an incoming sound is sounded; (2) participating in all teaching and learning activities well and actively; (3) doing good tasks; (4) following the extracurricular activities that he chooses; ( 5 ) having complete learning tools, for example books and other learning equipment; (6) attending the ceremony to commemorate religious / national holidays sena other events held at school; (7) participate in implementing SK; (8) do not leave the school / class before obtaining permission from the principal / teacher concerned; (9) participate in gymnastics organized by the school, and (10) comply with school regulations.

To enforce discipline, it is necessary to punish students who break it. Punishment is one of the supports of upholding discipline. This punishment is carried out when there is a violation of disciplinary rules in other words, students are required to learn to respect predetermined rules. So, enforcing discipline requires punishment for students who violate rules or regulations.

In addition to punishment, schools reward students who apply discipline. Reward (reinforcement) given to students who: cooperative. disciplined, creative, punctuality in assignments and so on. This is done as a stimulus in developing a sense of responsibility for students. Students will discipline themselves. This reward should not be given regularly, but if the student has something special to do, and the gift is sudden.

\section{c. Supervision}

Counseling guidance has an ideal concept and role, because with the optimal functioning of 
counseling guidance, all the needs and problems of students at school will be handled properly. Many students are reluctant to come to counseling because first, most students say they are embarrassed. Second, counseling guidance does not provide benefits for students because counseling officers themselves are less competent or their performance is still low. To anticipate this, the counseling guidance program should be prepared according to the needs of the subject, in other words the counseling guidance program must be good implementative and useful for students.

The program is a series of activities to be carried out to achieve the objectives of counseling guidance. This series of activities needs to be planned according to the conditions and situation of the school.

According to Natawijaya [4] mentions the characteristics of a good counseling guidance program as follows: (1) in planning a counseling guidance program involving all officers in schools; (2) having ideal goals, the reality of the implementation; (3) reflects good communication counseling guidance staff; (4) support the achievement of educational and teaching goals in schools; (5) provide services to all students; (6) there is a balance in: group and individual guidance services, services from several counseling guidance personnel in schools, use objective and subjective approach, counseling individually and in groups and the needs of individuals (students) and society [13].

\section{CONCLUSION}

Based on research and discussion, the conclusion can be drawn, among others: 1) planning of guidance prepared by the coordinator and assisted by a teacher BK BK; 2) the implementation of counseling consists of personal aspects, social aspects, learning aspects, career aspects, individual aspects, group aspects, and 3) supervision of counseling guidance.

\section{ACKNOWLEDGMENT}

This research is taken from the final project of the author at the PGRI University graduate program Palembang. Thank you Dr. H. Bukman Lian, MM, M.Si, Dr. Saiful Eddy, M.Si Dr. Happy Fitria, M.Pd . Dr. Edi Harapan, M.Pd and Dr. Rohana, M.Pd for their support and involvement during the writing of this article.

\section{REFERENCES}

[1] Fatah, G. (2017). Management of Education Based on Madrasah. Semarang: Rizki Putra Library.

[2] Hasibuan, M. (2005). Management, Basics,
Understanding and Problems. Jakarta: Earth Literacy.

[3] Incebacak, B., \& Ersoy, E. (2017). "7. Sinif Öğrencilerinin Matematiksel Muhakeme Becerilerinin Timss'e Göre Analizi." Journal of International Social Research 9.46 (2016).

[4] Marsudi, S. et al. (2003). Guidance and Counseling Services in Schools. Yogyakarta: Terrace.

[5] Masditou, M. (2017). Education Financing Management Towards Quality Education. ANSIRU PAI: Professional Development for Islamic Religious Education Teachers.

[6] Ministry of National Education. (2008). Guidance and Counseling in Schools, Directorate of Education Personnel, Directorate General of Quality Improvement of Teachers and Education Personnel.

[7] Ministry of National Education. (2004). Guidelines for the Implementation of Guidance and Counseling Services. Jakarta: Diknas.

[8] Mufron, A. (2013). Islamic Education Science. Yogyakarta: Aura Pustaka.

[9] Nugraha, A., \& Fitria, H. (2019). Infrastructure Management in Improving the Learning Process. In Proceedings of the National Seminar on the Postgraduate Program of PGRI Palembang University.

[10] Saefullah, U. (2013). Islamic Education Management. Bandung: Faithful Library.

[11] Samani, et.al. (2003). School Management Guidelines. Jakarta: Depdikbud.

[12] Shulhan, M., and Soim. (2013). Islamic Education. Jakarta: Bumi Aksara.

[13] Sudjana. (2004). Learning Strategies in Outside School Education. Bandung: Falah Production. 